\title{
A critique of the Global Pact for the environment: a stillborn initiative or the foundation for Lex Anthropocenae?
}

\author{
Louis J. Kotzé ${ }^{1,2}$ (D) Duncan French ${ }^{2}$ (D)
}

Accepted: 1 October 2018 / Published online: 15 October 2018

(c) The Author(s) 2018

\begin{abstract}
In May 2018, the process which may ultimately lead to the negotiation of a legally binding Global Pact for the environment formally commenced under the auspices of the United Nations General Assembly. Expectations for the Pact are high, evidenced in particular by its multiple and overlapping objectives: to serve as a generic binding instrument of international environmental law (IEL) principles; to integrate, consolidate, unify and ultimately entrench many of the fragmented principles of IEL; and to constitute the first global environmental human rights instrument. In the wake of the impending intergovernmental process, the paper offers a thorough critique of the draft Pact in its present iteration. We do so with the aim of evaluating the strengths and weaknesses of the present draft Pact by interrogating: (a) its diplomatic and symbolic relevance and possible unique contribution at the policy level to global environmental law and governance, and (b) its potential at the operational level of IEL and global environmental governance, focusing on the extent to which the draft Pact accommodates both existing and more recent rules and principles for environmental protection. As the Pact's primary ambition is to become a universally binding global treaty, it would be churlish not to recognise its potential for innovation, as well as the considerable opportunity that the negotiation of the Pact will have to generate broadsweeping and positive impacts. However, our central thesis is that only if the Global Pact were to incorporate ambitious normative provisions to strengthen those public and private global governance efforts that aim to halt the deterioration of Earth system integrity, as well as to maintain and improve integrity, will it be able to offer a firm foundation of the type of Anthropocene Law, termed here as the Lex Anthropocenae, required to confront head-on the deep socio-ecological crisis of the Anthropocene.
\end{abstract}

Keywords Global Pact for the Environment · Anthropocene - Lex Anthropocenae · International environmental law $\cdot$ Earth system $\cdot$ Multilateral environmental agreements · Soft law

Louis J. Kotzé is a member of the Group of Experts involved with the initial drafting of the Pact.

Louis J. Kotzé

lkotze@lincoln.ac.uk

1 North-West University, Potchefstroom, South Africa

2 Lincoln Law School, University of Lincoln, Lincoln LN6 7TS, UK 


$\begin{array}{ll}\text { Abbreviations } \\ \text { EMAS } & \text { European Union Eco-management and Audit Scheme } \\ \text { ECLAC } & \text { Economic Commission for Latin America and the Caribbean } \\ \text { HRC } & \text { Human Rights Council } \\ \text { ICJ } & \text { International Court of Justice } \\ \text { IEL } & \text { International environmental law } \\ \text { ILA } & \text { International Law Association } \\ \text { ILC } & \text { International Law Commission } \\ \text { ISO } & \text { International Organization for Standardization } \\ \text { IUCN } & \text { International Union for Conservation of Nature } \\ \text { MEAs } & \text { Multilateral environmental agreements } \\ \text { SDGs } & \text { Sustainable Development Goals } \\ \text { UN } & \text { United Nations } \\ \text { UNEA } & \text { United Nations Environment Assembly } \\ \text { UNEP } & \text { United Nations Environment Programme } \\ \text { UNGA } & \text { United Nations General Assembly } \\ \text { WCN } & \text { World Charter for Nature }\end{array}$

\section{Introduction}

In June 2017, the Global Pact for the Environment (Global Pact) was presented to the world in Paris with considerable fanfare and to significant media and broader public attention by the French think tank, Le Club de Juristes, which also coordinated its drafting process (World Commission on Environmental Law 2017). The final outcome of a relatively swift process that consisted of five consultations, the Pact was drafted by a Group of Experts ${ }^{1}$ : a network of over 100 lawyers representing almost 40 nationalities and chaired by Laurent Fabius, the president of Climate Change COP21, the current President of the French Constitutional Council, and recently appointed United Nations (UN) Environment Patron on Environmental Governance.

The Pact's objectives seem to be three-pronged: (1) to be a globally binding environmental law instrument; (2) to thus entrench all major principles of international environmental law (IEL) in one document; while also (3) developing progressively the law to provide a globally recognised right to live in an ecologically sound environment, with associated procedural environmental rights. The Pact also includes, inter alia, references to long-standing principles of IEL such as prevention, precaution and sustainable development, as well as the inclusion of newer principles such as resilience, non-regression and the role of non-state actors and subnational entities in environmental governance.

Expectations for the Pact are clearly high, as evidenced by the explicit support of the International Union for Conservation of Nature (IUCN), which has observer and consultative status at the UN, as well as by the support of French President Emmanuel Macron, who has resolved to "push the Pact through the United Nations General Assembly" (Le

\footnotetext{
1 As a draft text adopted by a broad consultative process, its present status and an authoritative source for its existence are difficult to formalise into traditional citation. The authors used the text available at: http://pactenvironment.emediaweb.fr/wp-content/uploads/2017/07/Global-Pact-for-the-Environment-proje ct-24-June-2017.pdf. Accessed 24 September 2018. It features in the bibliography as "Le Club de Juristes (2017b)".
} 
Club de Juristes 2017a: 8). France convened a "launch summit" as a side event to the highlevel segment of the 72nd session of the UN General Assembly (UNGA) on 19 September 2017, which led to France and supporting nations to bring forward a draft resolution to the UNGA. On 10 May 2018, the resolution was adopted by the UNGA (143 votes in favour, 6 against and 6 abstentions) ${ }^{2}$ (UNGA 2018). The stage is now set for states and other stakeholders to begin the process to consider the draft text with a view-so its supporters hope-of negotiating and adopting a final instrument. In particular, the resolution established an ad hoc open-ended working group to consider the matter (UNGA 2018: para. 2), to be guided especially by a "technical and evidence-based" report from the UN Secretary-General on "possible gaps in international environmental law and environment-related instruments" (UNGA 2018: para. 1). At an organisational session held in September 2018, it was announced that the Secretary-General's report would be received in November 2018 and that the working group would then meet at least three further times in 2019 to consider recommendations for next steps for the UNGA, which could include convening an intergovernmental conference to adopt a Global Pact (Lebada 2018).

In the wake of the impending political, diplomatic and legal processes to negotiate, refine, agree and possibly adopt the final text, we offer a critique of the draft Pact in its present iteration (see also Raith 2018; Biniaz 2017; Burger et al. 2018). We do so with the aim of evaluating the strengths and weaknesses of the Pact by interrogating: (a) its diplomatic and symbolic relevance and possible unique contribution at the policy level to global environmental law and governance (evidenced by the nomenclature of the "Pact" itself), and (b) its potential at the operational level of IEL and global environmental governance, focusing on the extent to which the draft Pact accommodates both existing and more recent rules and principles for environmental protection that are crystallising in treaty law, soft law and jurisprudence.

Throughout, we critically reflect on the extent to which the Pact contains the type of provisions that must respond to the socio-ecological crisis of the Anthropocene epoch in accordance with the dictates of an intertwined Earth system (Lewis and Maslin 2015). The Anthropocene Working Group recently concluded that there is probably convincing evidence to formalize the use of the term Anthropocene in the near future as the name for the new human-dominated geological epoch (Zalasiewicz et al. 2017: 59). Yet, formalised or not, the Anthropocene:

...is not simply a neutral characterisation of a new geological epoch, but it is also a particular way of understanding the world and a normative guide to action. It is ... more usefully understood as an ideology - in that it provides the ideational underpinning for a particular view of the world, which it, in turn, helps to legitimate. (Baskin 2015: 10-11 (emphasis added))

With reference to the Anthropocene's potentially far-reaching normative consequences, we agree with Dalby that "[T]he future configuration of the Earth System is now the key matter of geopolitics, of how the world is known, reorganized and rebuilt in the struggles for economic and political mastery in rapidly changing circumstances" (Dalby 2016: 34) and believe that a globally binding instrument such as the Pact might play a potentially significant normative and broader governance role navigating humanity through the Anthropocene.

\footnotetext{
2 The States voting against were Iran, Philippines, Russia Federation, Syria, Turkey and the USA, whilst the States abstaining were Belarus, Malaysia, Nicaragua, Nigeria, Saudi Arabia and Tajikistan.
} 
We commence the discussion in Part 2 below by broadly reflecting on the diplomatic, political and symbolic relevance of the Pact. We do so in particular by first discussing the possible message its drafters hoped to convey by designating it as a "pact" and not a "treaty", a "convention" or an "agreement". We then investigate one of the major objectives of the Pact, namely to strengthen the coherence of IEL by addressing fragmentation. The following section critiques the Pact's singular "environmental" focus and its failure to embrace an Earth system approach to IEL and global environmental governance, while the discussion also critically interrogates the related issue of the Pact's anthropocentric ontology. This part concludes with a discussion of a major potential drawback of the Pact in its present form: uncertainty with respect to its nature, form and purpose.

Part 3 forms the bulk of the discussion. Here we dissect in some detail and critique the provisions of the Pact, reflecting throughout on how far the text reflects recent developments or provides for any novel provisions, and thus the extent to which the provisions aspire to conform to, innovate and/or strengthen existing IEL.

We conclude the discussion in Part 4 with a critical reflection on whether the Pact presents a firm foundation for inaugurating or constituting the type of paradigm-shifting global juridical regime that we critically need in the Anthropocene (Lex Anthropocenae), or whether the Pact in its present form is a stillborn initiative and lost opportunity. We acknowledge that notwithstanding the limitations of a "paper" Pact, and that implementation is invariably pivotal (UNGA 2018: para. 1), ${ }^{3}$ an ambitious legally binding treaty is still hugely valuable, but only if it is appropriate. Our central thesis, however, is that only if the Global Pact were to provide normative provisions to strengthen those public and private global governance efforts that aim to halt the deterioration of Earth system integrity, as well as to maintain and even improve integrity, will it be able to offer a firm foundation of the type of Anthropocene Law, termed here as the Lex Anthropocenae, required to confront head-on the deep socio-ecological crisis of the Anthropocene (Kotzé 2017).

\section{Diplomatic, political and symbolic relevance}

In global (environmental) governance, symbolism might not necessarily lead to concrete results, but symbolism is important nevertheless, especially at a diplomatic and political level.

As Caldwell and Weiland state with reference to the World Charter for Nature of 1982 (WCN) (itself an instrument adopted by the UNGA but which, beyond its initial proclamation, has not again featured prominently in or exerted any significant norm-shaping influence on global environmental governance):

... [it remains a] significant symbolic expression of a hope among nations to achieve a more harmonious and sustainable relationship between humanity and the rest of the biosphere ... Symbolic expression is an important element in the development of public and international policy; it sets the context within which operational strategies and programs are developed. (Caldwell and Weiland 1996: 100)

What then is the symbolic, political and diplomatic relevance of the Pact?

\footnotetext{
${ }^{3}$ The report to be submitted to the Secretary-General, though its principal purpose is to identify and assess "possible gaps", is to written within the broader context of "with a view to strengthening their implementation".
} 


\subsection{The solemnity of a pact}

In determining the Global Pact's potential importance, one needs to consider the message that its drafters hoped to convey. It is significant that it has not been framed as a "declaration" like the Stockholm Declaration on the Human Environment of 1972 or the Rio Declaration on Environment and Development of 1992, a deliberate attempt to convey a specific normative message, to influence global perceptions and to avoid from the outset the pitfalls of ethically weak soft normativity generally associated with non-binding soft law declarations. After all, specifically as a result of the non-binding nature of the Stockholm and Rio Declarations, the impetus behind drafting the Pact was to offer a binding "international treaty establishing the fundamental principles of environmental law" in response to the "strong expectation from the legal community to see the foundations of environmental regulation systematised in a single instrument at an international level" (Le Club de Juristes 2017a: 23).

In pursuit of such binding normativity, the draft text is instead fashioned around the idea of a pact; an agreement espoused as a solemn promise without reservation among like-minded states that share common concerns whereby they purposively commit to undertake specific actions to achieve a certain objective to their mutual benefit. The word "pact", which has specific connotations, is a deliberate designation, we would suggest, and is reminiscent of related terms such as charters and covenants, which have been employed elsewhere in the past in attempts to respond to similar existential crises by imbuing global agreements with a distinct higher-order, ethically grounded, and universally binding character that imposes not only legal but also moral obligations on states, while announcing sweeping ethically driven paradigmatic changes in a way that pacts, covenants and charters typically aim to do (Nicholls 2010). Acknowledging the transactional nature of many international treaties, the term "pact"-alongside other terms such as "charter"- - seeks to signify something of significance, while also concealing that the international community has no other method, or form, of explicit environmental law-making (French and Scott 2018).

The possibly unique moral, political, diplomatic and ultimately juridical significance of the Global Pact's designation as such is illustrated through analogy by the USA' insistence on not designating the Rio Declaration during its negotiation phase as a charter, but instead as a declaration, believing that "the name 'Charter' raised unrealistic expectations about the document's legal content" (Kovar 1993: 123). Engel further highlights the special nature and significant (if often symbolic and abstract) importance of such instruments:

The image of covenant, and the rich constellation of ethical meanings that flow from it, have the greatest potential of enabling us to see the 'majesty and tragedy' of our contemporary global situation, as well as to coordinate the insights of other images of our moral condition ... The making of covenants is one of the oldest and most enduring ways in which human beings have established social relations founded on shared values and purposes. (Engel 2004: 3)

The United Nations Charter of 1945, which quite literally introduced a new world order, is such an instrument. Others are the (binding) International Covenants on Civil and Political Rights and on Economic Social and Cultural Rights of 1966, while the WCN and the Earth Charter of 2000 offer prominent soft law examples in the environmental domain (Bosselmann and Engel 2010). The word "pact" more specifically has 
already occurred in similar high-level and aspirational agreements that have sought to announce a watershed moment in international relations, such as the Pact of Bogotá of 1948 (officially known as the American Treaty on Pacific Settlement) aimed at the peaceful settlement of disputes in the Pacific region, and the Kellogg-Briand Pact of 1928 (officially known as the General Treaty for Renunciation of War as an Instrument of National Policy).

To this end, the obvious advantage of adopting a pact for global environmental law and governance arguably lies in the possibility that it could infuse largely Western-driven principles with an ethics-based, more representative, democratic, and thus legitimate global representation, not only of global civil society and state interests, but also of the myriad moral and ethical values they and other stakeholders collectively hold dear, including the collective obligations they have towards care for the Earth system. There is some evidence in the draft wording that this was consciously attempted. Leaning towards the approach of the global civil society-driven Earth Charter, the invocation of "pact" also seeks to broaden the diplomatic relevance and application of the Global Pact to non-state actors to the extent that it recognises: "[T]he Parties shall take the necessary measures to encourage the implementation of this Pact by non-State actors and subnational entities, including civil society, economic actors, cities and regions taking into account their vital role in the protection of the environment" (draft article 14), a complex and, in many respects, novel intervention bolstered by the fact that this initial version of the Pact emerged from civil society, as it has been drafted by non-state actors outside of the formal state-centred treaty-making system. In theory at least, this could result in the Pact being grounded in an orientation that transcends the realm of the purely state-based concerns that treaties invariably pursue, by instead seeking innovatively to accommodate (if not necessarily to impose) principles and provisions that states would not of their own volition normally include in treaty provisions. Whether this is the case is investigated below.

\subsection{Innovatively consolidating international environmental law?}

While the Pact's primary ambition is to become a universally binding global treaty, it would be churlish not to recognise its potential for innovation, and indeed, the considerable opportunity that the negotiation of the Pact will have to generate broad-sweeping and positive impacts. As noted earlier, it aims to integrate, consolidate, unify and ultimately entrench the fragmented principles of IEL. It is envisaged that the Pact "should strengthen the coherence of global governance of the environment, currently characterized by the fragmentation of international institutions and the multiplication of international environmental norms both technical and sectoral" (Le Club de Juristes 2017a: 8). To this end, such integration might itself be beneficial if it leads to an instrument that consolidates the leading principles of IEL into one overarching framework treaty that acts as a collective, single and authoritative reference point. And, as noted below, there is also some evidence of a certain amount of progressive development in the principles included. Thus, setting aside for the moment the question whether the present text is, on the one hand, attempting to be too ambitious or, on the other, perceived as not being ambitious enough, there are many who are prepared to accept the potential value in and of itself of seeking to adopt such a treaty, recognising also its potential to provide clearer direction for treaty interpreters to achieve systemic integration in public international law (Young 2018).

On reflection, and with some hesitation, we remain unconvinced. At a deeper, regulatory level, there is little conclusive evidence that addressing fragmentation in such a 
way will necessarily improve the overall effectiveness of global environmental governance in any aggregated sense (Kotzé 2014). It has been pointed out, for example, that fragmentation might actually be a desirable characteristic of global environmental law and governance for various reasons: because Earth system challenges are very diverse; because a one-size-fits-all governance approach is not compatible with Earth system complexities; because current IEL approaches and multilateral environmental agreements (MEAs) have been designed in a nuanced manner tailor-made for a specific issue area and its challenges; and because fragmented IEL regimes are considered on balance to be more flexible, reflexive and adaptive while allowing for innovation (Biniaz 2017: 2, cf Gupta and Sanchez 2012). If nothing else, a rush to codification for the purpose of integration should be carefully weighed up, as it is not invariably a "good" outcome in all situations.

Moreover, it is all but impossible for the Global Pact to provide for, and thus consolidate, all of the principles, provisions and institutions of IEL in one document. And if, as it does, it focuses only on consolidating the key principles of IEL with a view to also promoting legal certainty and normative clarity and consistency, it may be beneficial for that reason-in terms of its internal logic — but it will fail to address the underlying and deeply seated structural causes of the fragmentation of global environmental governance, such as the fact that environmental governance is by its very nature sectoralised (climate, water, forests, oceans, etc.) and governed by issue-specific treaties providing for specialised treaty governance bodies. There is no single global environmental government in the strict sense, with no prospect that such an organisation will emerge anytime soon. The United Nations Environment Assembly (UNEA) — as the now universalised global decision-making forum at the head of the United Nations Environment Programme (UNEP)—remains far from playing such a role. Ultimately, unless the Global Pact pursues its consolidation ambitions in tandem with efforts to strengthen global environmental governance, it will not improve the effectiveness of IEL overall. A similar argument could be made in terms of reforms to environmental dispute settlement (French forthcoming).

With respect to the novelty of its consolidation objective, such a project has of course already been pursued by the (non-binding) IUCN Draft International Covenant on Environment and Development of 1994, itself in part a response to the international community's own half-hearted conviction that such an endeavour is necessary (see, for instance, paragraphs 38 and 39 of Agenda 21). The IUCN Draft Covenant is intended to be "a blueprint for an international framework (or umbrella) agreement consolidating and developing existing legal principles related to environment and development" [IUCN 1994 (5th edn. 2015)]. If the ambition is merely to have a binding document that consolidates all major existing principles of IEL, states could simply revert to the IUCN Draft Covenant, which has been carefully developed over many years, and convert the Covenant into a binding instrument. This would serve the purpose of having a binding consolidating instrument for bindingness' sake, recognising that bindingness in form and bindingness in content are asymmetrical and that the former is not inherently to be preferred. Bindingness in itself, however, does not invariably improve environmental quality and the effectiveness of IEL, as it would not necessarily address the root causes of inadequate environmental protection, and it would miss an opportunity to meaningfully cater for associated but critically important considerations that have a bearing on the level of environmental protection, such as financial and technical assistance, capacity-building and institutional governance support (Biniaz 2017: 9). If the intention is (also) to provide for innovative, ethical and potentially more effective IEL provisions in a consolidated binding instrument, then future efforts at negotiation will instead have to focus on content and on adopting the type of provisions 
that are fit for purpose in the epoch of the Anthropocene, a matter to which we return in Part 3 below.

\section{3 "What's in a name?"}

While the use of the term "Pact" can be supported for the reasons outlined above, the choice of "Environment" as the Pact's descriptor, though seemingly innocuous, is not uncontentious for two principal reasons. First, both as a matter of regulatory conceptualism and epistemic value and utility, criticism can be increasingly levelled against the idea of "environmental protection", which has traditionally included-yet separated out-distinctive aspects such as wildlife conservation, pollution control and waste management often in a haphazard way that ignores not only ecological complexity but also important social (human) relations and their interactions. In tandem with more daring epistemological endeavours urging us to rethink "environmental" problems in more encompassing, reciprocally interconnected and holistic ways, there is increasingly a case to be made in support of discarding the term "environment" (and its accompanying terminological baggage of "sustainable development") on the grounds that the term has a chequered history and has gradually become unable semantically, conceptually and epistemically to respond to current demands.

Instead, new epistemologies urge a perspective centred on the Earth system that requires integrated modes of polycentric, reflexive and multi-scalar global law and governance alongside a systems approach (Biermann 2014). We would strongly argue for the necessity to future-proof the Pact, and to recognise an altogether more integrated systems approach that is fit for purpose, and which is expressed through contemporary concepts and ideas that act as epistemic lenses, incorporating the contribution of concepts such as planetary boundaries, Earth system governance and the Anthropocene. From a legal perspective, this would lead one to begin to talk about Earth system law, moving towards a Lex Anthropocenae, which hints at a transformed type of law grounded in and focused on the entire Earth, while promoting positive notions of the rule of ecological law, a transformed sense of global democracy, global ecological citizenship and the rights of nature; all collectively institutionalised within a new model of Earth system stewardship and governance (Bosselmann 2016).

The Earth system perspective is therefore not concerned only with discrete environmental concerns, but more broadly with all aspects of a deeply intertwined Earth system, of which human beings are only one part, including the myriad complex intertwined socioecological aspects of the Earth system. The inherently linked interdependence and reciprocity between people and Earth that are expressed through a systems approach would, we believe, have strengthened the symbolism of the promise of a Pact, while at once affirming the Anthropocene's central thesis that insists:

Humanity and nature are one, embedded from within the recent geological record. This is the core premise of the Anthropocene thesis, heralding a potentially far-reaching paradigm shift in the natural sciences as well as providing new models for thinking about culture, politics, and everyday interactions. (Haus der Kulturen der Welt 2013)

Had it incorporated a systems approach in its name and its provisions, the Pact would also have been better aligned with insights and perspectives emerging from within the UN itself; an increasing realisation that new concepts need to influence the shape, content and 
purpose of global environmental law and governance. For example, as recently as in 2014 the UNGA proclaimed that: "[E]arth system science has paved the way for Earth system governance, Earth-based law and Earth-based economics .... Each of these evolutionary changes, individually and together, point to a new path for us to ensure the well-being of the planet and its people". (UNGA 2014: para. 12) While it does not do so in its present form, if revised, the Pact might be the ideal normative vehicle to announce and usefully carry the Earth system perspective through the global environmental policy, normative, institutional and political architecture.

Second, from an ethical point of view and underlying the prevailing anthropocentric approach in international environmental law, "environment" is a term that is central to other instruments within the field, such as the Rio and Stockholm Declarations, both of which have been unsuccessful in juridically extending greater care to the non-human world. In these instruments and in other contexts, "environment" has the potential to relegate non-human entities to an objectified, purely utilitarian and commodified status, homogenised, in passive form, for human use and survival, which consequently also serves as the only reason to protect non-human life. While we do not suggest these instruments have been unsuccessful solely because of their reference to "environment", and while states are undoubtedly more inclined to support instruments with less ecocentric content, we do believe that the use of words such as "nature" or "Earth" that the WCN and the Earth Charter instead employ, imparts an altogether more solemn sense of sacredness and inclusiveness of human beings as part of the Earth system (Mackey 2004). By invoking the imagery of a caring mother Earth, or nurturing nature, the WCN centres on an altogether more ecologically inclined ontology, ${ }^{4}$ which corresponds with the Earth Charter's designation of "earth as our home". 5 If we destroy it, we have nowhere else to go. Had the Global Pact encapsulated such a notion already in its name, it might have gone a long way in signalling its intention to pursue an alternative, more radical paradigm of Earth system care and protection of this system's integrity. It would also have been a better fit for emerging high-level global political and diplomatic trends, such as the recent UNGA resolution promoting "life in harmony with nature" (UNGA 2009), that are moving slowly but evidently towards another paradigm of alternative ecocentric framings of Earth system care and responsibility.

Had the Global Pact instead been named, for example, as the Global Pact for Earth System Integrity, or simply "Global Pact for the Earth", it could have foregrounded far more explicitly and deliberately, if still admittedly only symbolically, a scientifically informed yet ethically driven approach to resolving the current socio-ecological regulatory problematique. It could also have signified that it is based on an ecological ontology that is more inclusive of human and non-human concerns. Other scholars have proposed the development of a "safe operating space treaty" or a "framework convention on planetary boundaries" that more fully responds to Earth system limits and that is based on the scientifically informed planetary boundaries theory and the need to safeguard Earth system integrity (Magalhães et al 2016; Fernández and Malwé 2018). Fanciful perhaps, but it has the benefit of not being framed in language that, while useful in the first modern epoch of environmental law in the 1970s, has been overtaken by alternative paradigms as we seek to better

\footnotetext{
${ }^{4}$ Preamble: "Every form of life is unique, warranting respect regardless of its worth to man, and, to accord other organisms such recognition, man must be guided by a moral code of action".

5 The Preamble to the Earth Charter also says human beings have a responsibility to protect their home; a responsibility which is "a common concern of all peoples".
} 
understand the highly complex Earth system. The Global Pact thus runs the risk-even in its name-of creating a dissonance between what it actually offers and that which is currently required at a scientific, diplomatic and political level. In these key respects, it is no more progressive than the Stockholm or the Rio Declarations. And if it is not progressive, as a legally binding text for future generations, does it thereby not run the risk of being inalienably regressive?

\subsection{A "Jack of all trades, master of none"?}

Going forward, if it is taken to completion, the negotiators will have to be very clear about the Pact's ultimate form and purpose. In its present form, it (perhaps too) ambitiously seeks to tick a whole range of boxes ranging from serving as a generic binding instrument that significantly raises the normative status of many principles of IEL; second, (not altogether unrelatedly but nevertheless distinctly and additionally) serving as a global umbrella instrument integrating, consolidating and unifying the many principles of IEL that lie scattered across the global normative scene; and third, serving as the first (if inchoate) global environmental human rights instrument. After all, if it is intended to be a global environmental rights instrument, it would do well to consider and incorporate much more expansively the work of the UN Special Rapporteur on Human Rights and the Environment (UN Human Rights Council 2018), and indeed the Human Rights Council in this area, in its attempt to raise global environmental protection to the international "constitutional" level (Kotzé 2016). The then Special Rapporteur on Human Rights and the Environment, John Knox, for example, has developed 16 Framework Principles (UN Human Rights Council 2018) which, if the Global Pact is to become the principal instrument on environmental rights, it should collectively and comprehensively elaborate the substantive and procedural aspects of the right to a healthy environment that are contained in these Framework Principles. As we point out below in greater detail, the Pact would also have to provide far more deliberately and extensively the entire panoply of human rights-related provisions, institutions, mechanisms and protective procedures usually found in human rights instruments, including among others those regulating the relationship with other human rights and human rights instruments, compliance and enforcement mechanisms and procedures, jurisdictional application and conflict resolution procedures. In short, it would have to become a global human rights instrument. On the other hand, if it aims to be a generic (i.e. summary in content) treaty on environmental matters, it will equally have to be very clear on its relationship with other current binding instruments of IEL, and it will have to provide clauses for resolution in case of normative collision between its provisions and those of another instrument. See, for example, the important norm-reconciliation provision in the Convention on Biological Diversity of $1992{ }^{6}$

Related to the issue of clarifying its nature is the diverse and often confusing focus of its regulatory provisions. As Biniaz points out, some of the Pact's provisions have an interstate application (for example, the preventive principle in draft article 5), while others are seemingly directed to domestic situations (for example, the right to access to information in draft article 9), ${ }^{7}$ and yet others are left open-ended (for example, the duty of care principle

\footnotetext{
6 Art 22: "(1) The provisions of this Convention shall not affect the rights and obligations of any Contracting Party deriving from any existing international agreement, except where the exercise of those rights and obligations would cause a serious damage or threat to biological diversity. (2) Contracting Parties shall implement this Convention with respect to the marine environment consistent".

7 See specifically Aarhus Convention (Article 3.7) and European Parliament (2018: para. 22).
} 
in draft article 2) (Biniaz 2017: 3). In addition, while states are most usually the main referent or subject of IEL, the Pact seeks to place some duties on individuals, such as its duty of care principle, which says "[E]very State or international institution, every person, natural or legal, public or private, has the duty to take care of the environment" (emphasis added). The discrepancy between the moral reach of the Pact's provisions and its normative effects is not altogether novel (see, among others, the Stockholm and Rio Declarations), and yet within the confines of a legally binding treaty—in contrast to soft law declarations-it is singularly more problematic.

This is not to say that the extension of the Pact to a whole range of state and non-state actors in diverse geographical and regulatory settings is not to be welcomed. In many respects, such an extension would be supported, as the extension of liabilities and obligations to non-state parties would better reflect the role such actors play in global environmental degradation and their accompanying responsibilities. But as draft article 14-as quoted above in part 2(1) — makes clear, the Pact does not ultimately depart from its traditional intergovernmental strictures, and thus, one must ask what value there is in including such provisions. Does it do so in the aspiration that States will domestically incorporate them, ${ }^{8}$ for purely symbolical reasons, or as recognition of the evolving nature of environmental principles? But this merely takes us back to the earlier question: what is the actual purpose of the Pact? It is that question which must remain at the forefront of the debate, as we now turn to consider the content of the Pact, beginning first with its preambular provisions.

\section{Operational level potential}

One of the major objectives of the Global Pact is to "enshrine the founding principles of environmental law" (Le Club de Juristes 2017a: 7). To this end, it seeks to consolidate all existing principles in one instrument. That the Pact is less focused on legal innovation than on normative integration and the consolidation of existing principles is clearly evident from Justice Fabius' introductory explanation accompanying the Pact that: " $[\mathrm{M}]$ ost of the principles contained in this text have already been agreed on in international environmental law" (Le Club de Juristes 2017a: 3). It is therefore by its own admission and that of its proponents mostly a restatement of the law, although as we note below the Pact does provide for a few novel provisions that are not yet widely contained in other IEL instruments, and even to a lesser extent, principles that already exist but which have been revised and consequently improved. We provide a summary below of its content, with the view to critiquing its operational potential.

\subsection{Preambular promises}

The Pact commences encouragingly enough in its preamble by calling for "ambitious" concerted global actions. With a nod to the Pact's forebears, it reasserts the Stockholm and

\footnotetext{
${ }^{8}$ Lord Carnwath, Justice of the Supreme Court of the United Kingdom, opines " $[\mathrm{I}] \mathrm{t}$ is indeed at national level, and in the national courts, that the Pact, like the Paris Agreement on Climate Change, may well have its main impact ... the Pact could provide a strong and principled framework for the interpretation and development of ... national laws within a shared global vision of the environmental rule of law" (Carnwath 2018).
} 
Rio Declarations (but surprisingly enough and for no apparent reason, not the Johannesburg Declaration on Sustainable Development of 2002, Rio + 20's The Future We Want, or Agenda 21). More innovatively and encouragingly, however, unlike almost any other global environmental instrument produced since the 1980s, the Global Pact explicitly reaffirms the provisions of the WCN, which is a "historic landmark in the evolution of global ethics" (Mackey 2004: 85) and still the only ecocentrically inclined global instrument that has been endorsed by the UNGA. The Charter is "[A] first attempt to free nature from human arbitrariness" and "to move beyond the anthropocentric and narrowly egocentric perspective of the modern world which sees nature to be there only for humans" (Moltmann 1991: 121). With its reference to the WCN, the preamble of the Pact raises expectations regarding the ontology of its subsequent substantive provisions, their ethical orientation and their possible rejection of neoliberal anthropocentrism in favour of an altogether stronger sense of ecological obligation and a high level of protection, on par with the provisions of the WCN. Unfortunately, this is an expectation that it does not meet, as we shall show below.

In sharp contrast to its acknowledgement of the WCN, the preamble then also reaffirms obligations in terms of the human development-oriented anthropocentric Sustainable Development Goals (SDGs) (for a recent comprehensive overview, see French and Kotzé 2018), thereby underlining the enduring centrality of sustainable human development as a focal point of the Pact's orientation (Kotzé 2018). And in true paradoxical form, the Global Pact is a mix of weak and strong sustainable development that, in trite anthropocentric terms, "allows each generation to satisfy its needs without compromising the capability of future generation [sic] to meet theirs, while respecting [in stronger ecocentric terms] the balance and integrity of the Earth's ecosystem". But with its explicit reference to the SDGs, the Pact remains aligned with the anthropocentric three-pillared approach to sustainable development, an approach which continues to be a convenient palliative (Richardson 2011), that legitimises at a high normative and political level the type of unbridled development that pushes ecological interests to the periphery of regulatory concerns, while prioritising social and economic development at the expense of both global Earth system integrity and of meaningful international solidarity between peoples.

The Pact highlights the "urgency to tackle climate change" and "unprecedented biodiversity loss", as well as the need to ensure that "ecosystems are resilient", but seemingly only so that ecosystems can "continue to provide essential services, thereby preserving the diversity of life on Earth, and contribute to human well-being and the eradication of poverty" (emphasis added). The important role of women in sustainable development is recognised, as are the rights and knowledge of indigenous peoples, local communities, migrants, children, persons with disabilities and people in vulnerable situations, reflecting some of the provisions - if not always the precise language - of the Rio Declaration. The need to "respect, promote and consider ... obligations on human rights" is explicitly stated, but it is particularly striking that states' human rights obligations are only confined to the "need to respect, promote and consider" and not the more generally accepted (and arguably more far-reaching) duties to respect, protect and fulfil their human rights obligations. ${ }^{9}$

Recognising the indispensable role of non-state actors in global environmental governance, the preamble then highlights the "vital role" of civil society, economic actors, cities, regions and other subnational authorities in environmental protection, while stressing the "fundamental importance of science and education for sustainable development". It

\footnotetext{
${ }^{9}$ See, among others, the language used in the three instruments comprising the International Bill of Rights, and the Guiding Principles on Business and Human Rights (UN Human Rights Council 2011).
} 
concludes by recognising the need for action to be guided by inter-generational and intragenerational equity (the latter of which is strangely omitted later from its operative provisions, as is any notion of international solidarity), and more rhetorically, an idealistic affirmation of the "need to adopt a common position and principles that will inspire and guide the efforts of all to protect and preserve the environment". Again, if this is to be a legally binding treaty, what is the legal status of "inspire and guide"? It may be a valid recognition that jurisprudentially as principles they are more open-textured than rules (Beyerlin 2007: 425), but the addition of "the efforts of all" would seem to open up the possibility of a more worrying conclusion: that the ambivalence of what the Pact is and to whom it is addressed (as discussed above) has permeated the text itself. Neither fish nor fowl-will the Pact survive the scrutiny that comes with intergovernmental analysis?

In sum, the preamble contains several contradictions, and aside from its recognition of the WCN and the concept of ecosystem integrity, there is very little in the Pact's preambular provisions specifically providing for non-human life protection, justice and integrity, or principles recognising Earth system limits and integrity. The preamble also largely ignores the issue of distributional inequality that is the bedrock of much environmental destruction, as well as the necessity of enhanced global cooperation in the form of international solidarity in which to begin to tackle global environmental destruction. Currently, the preamble offers almost nothing new, innovative or different from that which has already occurred in all global environmental declarations since 1972.

\subsection{A turn to rights?}

Immediately following its preamble is the human right to an ecologically sound environment, which says: "[E]very person has the right to live in an ecologically sound environment adequate for their health, well-being, dignity, culture and fulfilment" (draft article 1). Its inclusion at the very start of the Pact's substantive provisions is important, as it confirms the significant weight attributed to it, the fact that this would be the first global treaty to recognise such a right, and even its centrality as a potential Grundnorm of the Pact itself and possibly of global environmental law and governance [a fact also recognised by the former UN Special Rapporteur on Human Rights and the Environment in 2018 (Knox 2018)]. The right's formulation in the Pact corresponds with the general formulations of a human right to a healthy environment found in many domestic constitutions and in regional human rights instruments (O'Gorman 2017; Boyd 2011). The Pact's draft environmental right provision aims to promote an ecologically sound environment for the benefit of human development, and not for the sake of nature or for preserving the integrity of the Earth system. It is a far cry from the emerging non-anthropocentric rights of nature provisions and jurisprudence aimed at safeguarding ecological integrity that are now found in several countries such as in Bolivia, Ecuador, Columbia, New Zealand and some states in the USA (Kotzé and Calzadilla 2017; Calzadilla and Kotzé 2018).

But while the formulation of its environmental right provision is not particularly innovative or potentially far-reaching, the simple fact of its inclusion is nevertheless commendable. Currently, apart from the Stockholm Declaration, which implicitly hints at the existence of a right to a healthy environment (Principle 1), no other global environmental or human rights instrument, hard or soft, provides for such a right. The Pact thus responds to the former Special Rapporteur on Human Rights and the Environment, John Knox's recommendation in his final report, namely, that the Human Rights Council must "consider supporting the recognition of the right in a global instrument" (UN Human Rights Council 
2018: para. 14), though, as noted above, the mere inclusion of the right without further provision would be an inchoate insertion of a human rights approach. Nevertheless, the Pact could play a major part in such an endeavour, the possibility of which is also recognised by its proponents themselves, who have an ambitious anticipation that the Pact will represent the "third generation of [environmental] rights" (World Commission on Environmental Law 2017), and be "to the Rio Declaration [of 1992] what the 1966 International Covenants [International Covenant on Civil and Political Rights and the International Covenant on Economic, Social and Cultural Rights] are to the 1948 Universal Declaration of Human Rights" (Le Club de Juristes 2017a: 32).

But if it does retain (and hopefully deepen) its environmental right provision, because the Pact's nature and designation will impact on both its normative status and its focus, it will have to be clear about whether it is foremost a globally binding human rights instrument with associated (secondary) IEL principles that are necessary to respect, protect and fulfil the environmental right (thereby becoming part of the panoply of the arguably higher-order International Bill of Rights) or whether it is a generic global environmental agreement, rather similar to a multilateral environmental agreement (MEA), which just happens also to contain a substantive environmental right provision that operates alongside various other provisions. As we have noted above, this question is stylistic on one level, but on another it is a matter of substance, and importantly of treaty interpretation. The present iteration suggests that the Pact as a whole can best be explained as being more akin to the latter, which correspondingly suggests that the provision will less likely be able to give meaningful effect to the right to live in an ecologically sound environment as the newest legally entrenched global human right. Of course, the mere inclusion of such a right is not to be rejected, for this reason, but its longer-term impact will undoubtedly be influenced by the context (and the other content) in which it occurs. ${ }^{10}$

Complementing the substantive right to a healthy environment, draft articles 9-11 provide for rights-based aspects of environmental democracy by setting out procedural environment-related human rights including the rights to access to information, public participation, and access to environmental justice. Although the rights are presently operative predominantly only in Europe through the Aarhus Convention on Access to Information, Public Participation and Access to Justice in Environmental Matters of 1998 (Aarhus Convention), the provisions of this convention are detailed and backed by a complex institutional machinery. Thus, it already comprehensively, and some would say successfully covers, protects and enforces these aspects (Hey 2015). A similar treaty-the Escazú Agreement on Access to Information, Participation and Justice in Environmental Matters in Latin America and the Caribbean (Escazú Agreement)—-has opened for signature in September 2018 for Latin America and the Caribbean. ${ }^{11}$ Unlike both treaties, however, the Global Pact does not provide for a compliance procedure to address complaints of rights

\footnotetext{
10 Art 31(1) Vienna Convention on the Law of Treaties 1969: "A treaty shall be interpreted in good faith in accordance with the ordinary meaning to be given to the terms of the treaty in their context and in the light of its object and purpose".

11 Adopted under the auspices of the UN Economic Commission for Latin America and the Caribbean (ECLAC) at Escazú/Costa Rica on 4 March 2018, and opened for signature at the UN Secretariat in New York on 27 September 2018. The Escazú Agreement on Access to Information, Participation and Justice in Environmental Matters in Latin America and the Caribbean is far from being a direct copy of the Aarhus Agreement, and there are some important additions including the principles of non-regression and of progressive realisation (art 3) and an obligation to protect human rights defenders in environmental matters (art 9).
} 
infringements. In the case of the Aarhus Convention, its compliance mechanism is a unique innovation in IEL which allows members of the public to communicate grievances about a Party's compliance directly to a board of independent experts, which can then make recommendations to the Meeting of the Parties (Ebbesson et al 2014). Of course, the majority of states remain outside these regimes and thus not subject to anything other than the aspirational terms of Principle 10 of the Rio Declaration, which both the Aarhus Convention and Escazú Agreement more fully give effect to. Thus while it might be argued that the procedural rights set out in the Pact only provide general obligations, they would nevertheless be a significant development for much of the international community. Nevertheless, it remains the case that the lack of detail in the Pact would leave the implementation of these rights solely to the discretion of states, with limited prescription applying on how to enact or to ensure compliance. In this sense, simply measured against what has shown to already exist in IEL — now in both the Global North and the Global South - the procedural environmental rights enunciated in the Pact are a clear regression and they can be nothing but hortatory in effect.

\subsection{Duty of care}

The Pact provides in draft article 2 for a broadly formulated duty of care, which might rightly be seen as a natural corollary to the right to an ecologically sound environment (Payne 2018): "[E]very State or international institution, every person, natural or legal, public or private, has the duty to take care of the environment. To this end, everyone contributes at their own levels to the conservation, protection and restoration of the integrity of the Earth's ecosystem" (draft article 2). Whether or not such a broad duty of care across such a diverse range of actors could be said strictly to be an existing principle of IEL, this is a comprehensive formulation establishing a thoroughgoing and all-embracing duty of care that is potentially applicable to a wide range of state and non-state entities. Though not a novel provision - something similar exists in the Stockholm Declaration ${ }^{12}$-we would suggest it is nevertheless innovative, particularly if taken literally to expand the application of the Pact horizontally to non-state entities, such as transnational corporations. To date, corporations still do not incur any meaningful human rights obligations; Ruggie's Protect, Respect and Remedy: a Framework for Business and Human Rights (Ruggie 2008), though progressive in many respects, relies on traditional jurisdictional boundaries between international and domestic law.

Of course, as noted above, one must note the technique often used in soft law to include moral injunction opposable to all, and more precise rule opposable only to some (namely states). But, of course, the Pact is not meant to be soft law. And thus, how is such a provision meant to be understood? Previous attempts to impose direct legally binding international rules on transnational corporations ${ }^{13}$ met with derision and scorn. The same would arguably be true here. If, on the other hand, there was no intention to impose such an

\footnotetext{
12 Which provides in its Preamble: "[T]o achieve this environmental goal will demand the acceptance of responsibility by citizens and communities and by enterprises and institutions at every level, all sharing equitably in common efforts. Individuals in all walks of life as well as organizations in many fields, by their values and the sum of their actions, will shape the world environment of the future".

${ }^{13}$ UN Economic and Social Council (2003: para. 1): "Within their respective spheres of activity and influence, transnational corporations and other business enterprises have the obligation to promote, secure the fulfilment of, respect, ensure respect of and protect human rights recognized in international as well as national law, including the rights and interests of indigenous peoples and other vulnerable groups".
} 
obligation, what notion of "duty" as a legal concept is this, within a binding treaty? Unless the Pact challenges the systemic nature of intergovernmental relations, such horizontal application will be limited to that implemented in domestic law. In its present draft form, the Pact does not challenge the traditional norms of international personality.

\subsection{Sustainable development and equity}

Draft article 3 reaffirms the centrality of, and critical need to pursue, "sustainable development", but unlike the duty of care principle discussed above, this provision curiously seems to be aimed at state parties only, and not also at non-state parties. This is a critical oversight, since non-state actors such as transnational corporations are often those that most negatively impact on Earth system integrity, whereas the objective to achieve sustainable development is not, and has never been, an exclusive public governance function, as the now firmly established and widely practised private sector-focused European Union Eco-management and Audit Scheme (EMAS) and ISO 14001 environmental management standards, among others, suggest.

Moreover, though politically not an unsurprising inclusion, the Pact's invocation of "sustainable development" perpetuates the contested-though widely held-myth that it is possible to achieve ongoing, and even to expand, economic human growth within a limited Earth system. Like associated oxymorons such as "environmental resources", "ecosystem services" and "green economy", it does not offer a radically different alternative for steering human actions on a path of greater Earth system integrity and care (Redclift 2005). Ultimately, the Pact's endorsement of sustainable development as a critical objective for states to achieve, ensures that it is no different from any other global environmental declaration to date in terms of its long-term objective and underlying ethos.

Sustainable development is an easy phrase to repeat but much more difficult to convert into a legal obligation. ${ }^{14}$ Thus, from a legal perspective the language the Pact uses, also, is problematic. As with many of the draft articles, there seems to have been little attempt to integrate recent jurisprudence, especially of the International Court of Justice (ICJ), into the wording of the draft article. Draft article 3, for instance, would have done well to consider the ICJ's judgement in Pulp Mills on the River Uruguay (ICJ Reports (2010) 14), where the court sought to develop sustainable development from being a platitude (as it had used it in Gabčíkovo-Nagymaros Project (Hungary/Slovakia) ICJ Reports (1997) 7), ${ }^{15}$ and begin to address its normative implications. ${ }^{16}$ Another attempt was, for instance, also previously made by the International Law Association (ILA) Committee on International Law on Sustainable Development. ${ }^{17}$ It is still at a level of abstraction, but one can begin to

\footnotetext{
${ }^{14}$ Draft article 3 would seem to suggest two principal legal techniques to achieve sustainable development: (i) integration ("Parties shall integrate the requirements of environmental protection into the planning and implementation of their policies and national and international activities"), and (ii) the "promotion of public support policies, patterns of production and consumption".

15 ICJ Reports (1997) 7, 78: "This need to reconcile economic development with protection of the environment is aptly expressed in the concept of sustainable development".

16 For instance, ICJ Reports (2010) 14, 75: "[the] interconnectedness between equitable and reasonable utilization of a shared resource and the balance between economic development and environmental protection that is the essence of sustainable development".

17 See, for instance, the International Law Association (2012) Sofia Guiding Statements, including Guiding Statement (1): "Recourse to the concept of 'sustainable development' in international case law may, overtime, reflect a maturing of the concept into a principle of international law, despite a continued and genuine reluctance to formalise a distinctive legal status"; and Guiding Statement (2): "Treaties and rules of customary international law should be interpreted in the light of principles of sustainable development; interpreta-
} 
identify key features. Drafting difficulties to one side, the Global Pact as presently worded would seem to lack the detail-however inchoate-necessary to reflect the development of the concept over the last 25 years.

Draft article 4 then sets out the duty to observe and ensure inter-generational equity, which has traditionally always been related to the issue of achieving sustainable development. As referenced above, it is unclear why the drafters of the Pact chose to ignore the critical issue of intra-generational equity at a time when there are clear inequalities between people on Earth; inequalities that are vividly exemplified through the North-South divide (Gonzales 2017). Related to the decision not to include a rights of nature provision in the Pact, they also ignored the issue of intra-species equity, which is surprising considering that many pervasive climate and broader environmental injustices abound not only between human beings of this and the next generation, but also between human and non-human entities of this and the next generation. It is also disconcerting, as Raith notes, that other equity-related principles such as the equitable use of shared or common natural resources, and common responsibility for collective interests and goods including common areas, common heritage and common concern, have not been included (Raith 2018: 14). The Pact's view of equity is decidedly narrow and exclusionary, and despite its grand claims, it is far from being comprehensive in any meaningful sense. In fact, in this regard the Pact could be considered a clear regression from the well-established IEL principles of inter- and intra-generational equity.

\subsection{More of the same}

Draft articles 5-8 in broad terms repeat, without much effort to revise or "update" them, traditional IEL principles that one also finds in numerous soft law instruments and MEAs, including the principles of prevention (with the corresponding and well-established obligation to undertake an environmental impact assessment), ${ }^{18}$ precaution, the remediation of environmental damages, as well as state duties to inform one another and to cooperate, and the polluter pays principle. They seem simply to have been "copied and pasted", while no apparent thought was given to reframing them in terms of emerging case law, realities or progressive moves forward. They are neither innovative nor sufficiently radical to represent anything markedly different from what IEL already offers.

There are also numerous omissions both of principles themselves and of nuances within those listed. Four instances are given as sufficient examples of the obvious omissions in the text. First, the Pact fails to include, for instance, principle 23 of the Rio Declaration: "The environment and natural resources of people under oppression, domination and occupation shall be protected". A controversial provision yes, ${ }^{19}$ but one that is still hugely relevant.

\footnotetext{
Footnote 17 (continued)

tions which might seem to undermine the goal of sustainable development should only take precedence where to do otherwise would undermine fundamental aspects of the global legal order, infringe the express wording of a treaty or breach a rule of jus cogens".

18 Though the Pact fails to reference explicitly, in the case of potential transboundary harm, the recognition of the now customary nature of the obligation to undertake an environmental impact assessment (see Pulp Mills ICJ Reports (2010) 14, 83).

19 See, for instance, UNGA (2017: para. 6): "Israel, the occupying Power, to bring a halt to all actions, including those perpetrated by Israeli settlers, harming the environment, including the dumping of all kinds of waste materials, in the Occupied Palestinian Territory ... which gravely threaten their natural resources, namely water and land resources, and which pose an environmental, sanitation and health threat to the civilian populations".
} 
Second, in a more nuanced way, the Pact ignores the significant case-law developments on the issue of due diligence, ${ }^{20}$ as a way of holding States to account and as the measure by which States are held to account for the actions of private actors under their jurisdiction and control. ${ }^{21}$ There are arguments, of course, as to how far the case-law developments related to due diligence can be generalised outside their particular dispute matrix (International Law Association 2014, 2016), but to ignore such developments altogether seems short-sighted and regressive. Third, there is no engagement with the International Law Commission's (ILC) work on the prevention of transboundary harm (UN 2007: 148-170), which is particularly striking as the ICJ has had occasion to consider the issue in significant detail (Costa Rica v Nicaragua and Nicaragua v Costa Rica ICJ Reports (2015) 665). Instead, the language of the draft articles looks cursory and lacking in depth. For instance, draft article 5 instead of stating "The necessary measures shall be taken to prevent environmental harm" might have borrowed from Pulp Mills on the River Uruguay, mutatis mutandis, to strengthen the obligation: "A State is thus obliged to use all the means at its disposal in order to avoid activities which take place in its territory, or in any area under its jurisdiction, causing significant damage to the environment of another State" (ICJ Reports (2010) 14, 56) (emphasis added).

Fourth, the provision on precaution is notably weak and lacks both detail and substance. Whereas draft article 6 is unduly summary in form, ${ }^{22}$ recent case law has developed the language in some important respects. The Seabed Dispute Chamber's 2011 Advisory Opinion, for instance, has highlighted an important and evolving dynamism to precaution. ${ }^{23}$ This is also the case with the draft provision on the remediation of environmental damage. ${ }^{24}$ If this is where nearly 30 years of legal and political debate has taken us, or more

${ }^{20}$ See, for instance, Pulp Mills ICJ Reports (2010) 14, 79: "obligation to act with due diligence in respect of all activities which take place under the jurisdiction and control of each party. It is an obligation which entails not only the adoption of appropriate rules and measures, but also a certain level of vigilance in their enforcement and the exercise of administrative control applicable to public and private operators, such as the monitoring of activities undertaken by such operators, to safeguard the rights of the other party".

${ }^{21}$ Responsibilities and obligations of states sponsoring persons and entities with respect to activities in the area, International Tribunal on the Law of the Sea (ITLOS) Reports (2011) 10, 60: "Under international law, the acts of private entities are not directly attributable to States except where the entity in question is empowered to act as a State organ...or where its conduct is acknowledged and adopted by a State as its own".

22 "Where there is a risk of serious or irreversible damage, lack of scientific certainty shall not be used as a reason for postponing the adoption of effective and proportionate measures to prevent environmental degradation".

${ }^{23}$ Responsibilities and obligations of states sponsoring persons and entities with respect to activities in the Area ITLOS Reports (2011) 10, 46: "the precautionary approach is also an integral part of the general obligation of due diligence...This obligation applies in situations where scientific evidence concerning the scope and potential negative impact of the activity in question is insufficient but where there are plausible indications of potential risks". It is also worth noting what the Chamber thus says about due diligence: "“due diligence" is a variable concept. It may change over time as measures considered sufficiently diligent at a certain moment may become not diligent enough in light, for instance, of new scientific or technological knowledge. It may also change in relation to the risks involved in the activity" (ITLOS Reports (2011) $10,43)$.

24 "The necessary measures shall be taken to ensure an adequate remediation of environmental damages". Cf. Certain Activities carried out by Nicaragua in the Border Area (Costa Rica v Nicaragua) Compensation owed by the Republic of Nicaragua to the Republic of Costa Rica Judgment of 2 February 2018. Admittedly this is a recent case and it was not decided when the Draft Pact was written, but it should be taken into consideration during future drafting processes. 
accurately as far as the drafters felt they could go, then this is a damning indictment of IEL indeed. In all cases, the operational aspect of the Pact seems to have been subjugated to the perceived advantage of the mere inclusion of such principles in the text, seemingly merely for inclusion's sake. But is this sufficient?

For those principles, however phrased, which are included in the Pact, other questions arise, notably as to what the relationship may be between these principles in the Pact and the instruments and customary rules where they otherwise arise. Biniaz correctly notes that principles such as polluter pays, prevention, precaution and environmental assessment appear within a very specific context in numerous different MEAs and other soft law instruments, and they have been incorporated in each of these instruments for a specific reason. The open-ended generic nature within which they have been framed in the Pact would make it difficult to establish which instrument's principle would prevail if they were ever to come into conflict. More fundamentally, one might question their inclusion in the first place, since they have had limited demonstrable success in improving global environmental quality, either on their own, or as part of other MEAs. The inclusion of emerging and more radical principles such as in dubio pro natura, the need to protect Earth system integrity, intra-species justice and equity, extending legal subjectivity to non-human entities, and others, could have gone a long way towards raising this bar, a matter which we return to below.

\subsection{Environmental education and technological innovation}

Draft article 12 sets out parties' commitment to promoting environmental education, a "softer" but nevertheless critically important obligation that should in theory promote efforts to advance societal understanding and responses to environmental degradation. Somewhat relatedly, draft article 13 implores parties to promote "the improvement of scientific knowledge of ecosystems and the impact of human activities". It further asks of parties to cooperate through the exchange of scientific and technological knowledge "by enhancing the development, adaptation, dissemination and transfer of technologies respectful of the environment, including innovative technologies". Considering that technological innovation will probably play a key role in adaptation, also with a view to becoming more resilient in the face of an increasingly erratic Earth system, this is a potentially useful provision relevant to the concerted pursuit of alternatives for survival in the Anthropocene (Haff 2014).

However, the obligations that state and non-state actors derive from this provision are non-peremptory, and parties are only encouraged to strive to "promote, to the best of their ability" the improvement of scientific knowledge and innovation. Although it encourages "technologies respectful of the environment", the provision is also silent on prohibiting the effects of harmful technologies, such as nuclear activities, that disrupt Earth system equilibrium. In so doing, the Pact only embraces the benefits of technological innovations and does not address the substantial potential harms that could be caused by environmental technologies. Also, the obligation to cooperate and to develop technologies does not 
explicitly include the giving of assistance to those who need it most, namely developing and least developed countries.

The critical importance of indigenous knowledge systems in relation to the Earth system is also not recognised at all. Considering that indigenous knowledge plays a prominent role in radically reshaping environmental, human rights and other norms (for example, the indigenous notions of Pachamama and Vivir Bien that are foundational to Ecuadorian and Bolivian rights of nature laws), this is a potentially serious sidelining of non-Western views that works further to exclude already marginalised and peripheral indigenous worldviews in an increasingly neoliberal, industrialised, "modernised" world and its hegemonic system of public international law. As a Global Pact, critical third world scholars would remind us to ask whose globe we are referring to (Chimni 2006).

\subsection{Non-state actors and global environmental governance}

Draft article 14 innovatively extends the relevance, if not the application, of the Pact beyond the usual state actors by providing that states "shall take the necessary measures to encourage the implementation of this Pact by non-State actors and subnational entities, including civil society, economic actors, cities and regions taking into account their vital role in the protection of the environment" (own emphasis). This provision is broadly similar to the non-state actor application of the duty of care provided in article 2, but it is a far weaker formulation in that encouragement does not amount to enforcement, but recognises the limitations of traditional public international law. Whether this renders the provision toothless is a matter of political ambition and implementation, but we find it problematic nevertheless considering that considerable Earth system impacts are occasioned by nonstate actors. Moreover, as we have pointed out above, no explicit liability is set out for Earth system harm caused by non-state actors such as transnational corporations.

\subsection{Effective environmental laws}

Apparently mimicking principle 11 of the Rio Declaration which provides that "[S]tates shall enact effective environmental legislation", draft article 15 of the Pact says parties "have the duty to adopt effective environmental laws, and to ensure their effective and fair implementation and enforcement". There is no indication in the text of the Pact itself of what the term "effective" entails, but it could possibly relate to normative effectiveness, i.e. adherence to specified minimum standards that should arguably also be informed by proper science and that should improve environmental quality or avoid its deterioration. A similar technique can be found in the North American Agreement on Environmental Cooperation of 1993, the environmental side agreement of the North American Free Trade Agreement, where the states parties are encumbered "with the aim of achieving high levels of environmental protection and compliance with its environmental laws and regulations, each Party shall effectively enforce its environmental laws and regulations through appropriate governmental action" (Article 5). Of course, the latter provision does not stand alone but exists within an institutionalised and procedural framework of consultation and dispute resolution which, as noted below, is largely absent from the Global Pact.

One would also have expected the inclusion of a generic minimum threshold such as Earth system integrity, which provides the aspirational (albeit abstract) minimum that environmental law must achieve. Thus, if an environmental law norm is not sufficient in either preventing the decay of Earth system integrity; and/or maintaining Earth system integrity; 
and/or enhancing Earth system integrity, it would be ineffective. Another possibility would be to incorporate the planetary boundaries as a generic threshold into the Pact. These boundaries are based on "a sound scientific knowledge base that has been developed over the past several decades" (Kim and Bosselmann 2013: 289), and they determine a safe operating space for humanity within a compromised Earth system while offering a concrete vision of the limitations of the planet (expressed as boundaries) to sustain all life in the wake of increasing anthropogenic pressures (Rockström et al 2009). An incorporation of the planetary boundaries as thresholds would accommodate the view that:

... effective environmental legislation must at a minimum act as legal boundaries that prevent human activities from reaching and breaching planetary boundaries, defined as the safe space for mankind to operate within... In other words, legal boundaries must translate the physical reality of a finite world into law and thereby delimit acceptable levels of human activity. (Chapron et al. 2017: 1)

Related to the provision on effective environmental laws is draft article 17, which sets out the principle of non-regression, and which determines that "[P]arties and their sub-national entities [must] refrain from allowing activities or adopting norms that have the effect of reducing the global level of environmental protection guaranteed by current law". While it is a potentially impactful and useful provision, and is largely novel in IEL up to now, ${ }^{25}$ we believe the non-regression principle could have been taken further, to have also provided for the duty to improve the level of environmental protection offered by current laws. Maintaining the current level of protection, or the status quo, means we would in effect be maintaining the legal regime that contributed to the conditions that caused the Anthropocene in the first place, which would be an untenable situation for obvious reasons. Even the Paris Agreement on Climate Change of 2015, which is far from perfect, has done much to introduce the idea of ongoing normative progression within IEL: "[E]ach Party's successive nationally determined contribution will represent a progression beyond the Party's then current nationally determined contribution and reflect its highest possible ambition" (Article 4.3). It is a pity that this reasonably new approach has not also been incorporated in the Pact.

\subsection{Resilience}

Similarly, the Paris Agreement sets out in several provisions the objective to increase the resilience of people and of ecosystems in the context of climate change (Articles 2, 7, 8 and 10). Draft article 16 of the Global Pact places a more generic (i.e. non-climate change specific) obligation on states to increase the resilience of people and ecosystems: "[P]arties shall take necessary measures to maintain and restore the diversity and capacity of ecosystems and human communities to withstand environmental disruptions and degradation and to recover and adapt". While it is therefore not a novel provision, it is entirely appropriate, considering that concerns around safeguarding and improving resilience will become ever more present and critical in the Anthropocene (Grove and Chandler 2017). We would caution, however, against an overt reliance on resilience as a stand-alone concept without reference to its politico-legal context. ${ }^{26}$ In particular, we would suggest-as a matter

\footnotetext{
25 See, however, the previous reference to art. 3 of the 2018 Escazú Agreement on Access to Information, Participation and Justice in Environmental Matters in Latin America and the Caribbean.

${ }^{26}$ Cosens (2013: 3): "The key difference between social and ecological systems is that the actors in the social system have the ability to exercise free will and conscious thought. Thus, the social system may choose whether or not to foster resilience in the ecological system" (emphasis added).
} 
of terminology - that it be amended to make it explicit that it is not only about human resilience, but also about the resilience of non-human life, as well as Earth system resilience. While the current draft provision does not do so, any revision must acknowledge that vulnerable people mostly living in the Global South, especially in low-lying island states, are the least resilient to Earth system changes and that they require special attention and assistance. Otherwise, resilience risks becoming a narrow, technical and anthropocentric objective, focusing on ex post facto actions and not demanding systematic preventative measures, while at once ignoring critical issues of global equity, justice, solidarity and cooperation between countries.

\subsection{Miscellaneous}

The remainder of the Pact deals, often in somewhat trite terms, with numerous substantive and procedural issues one also finds in other global environmental agreements, namely: global cooperation, armed conflict, the principle of common but differentiated responsibilities, monitoring and implementation (substantive issues); and secretarial arrangements, signature and ratification, entry into force, denunciation and depository (procedural issues). We focus below on the substantive issues.

Starting with draft article 18, the Pact explicitly highlights the importance of global cooperation to facilitate its implementation with a specific view to conserving, protecting and even restoring the integrity of the Earth's ecosystem and community of life. Its reference to "ecosystem integrity" is encouraging, as is its inclusion of the term "community of life", which, being non-specific, might be broad enough to embrace non-human life as well. And yet cooperation is both complex and imperative in IEL. The limited conceptualisation of cooperation in draft article 18 does not do justice to the range of such obligations in the current law, never mind stretching it as de lege ferenda. In which case, if this is to be the new "go to" document, what does that say about the Pact's true level of ambition?

According to draft article 19, states must take, pursuant to their numerous other relevant obligations under international law, "all feasible measures to protect the environment in relation to armed conflicts". This is a commendable provision considering that immense environmental damage is associated with armed conflict (as the past and ongoing wars in the Middle East aptly suggest). But as a statement on the present law, this provision is rather scant and, like draft article 18, fails to reflect adequately current law, and thus raises questions as regards more recent developments scattered across the international humanitarian, criminal and environmental law plane. ${ }^{27}$ What draft article 19 also regrettably fails to do is to provide for addressing armed conflicts that could emanate from (shared) resource use, environment-related migration and climate change, among many other factors. This is a crucially growing concern that remains unresolved (Klare 2002), with a window of opportunity now opening through its inclusion in the Pact for its regulation.

As has already been noted, in some of its provisions the Pact fails to specifically recognise the interests of developing countries. But with a nod in the direction of the everdeepening North-South divide, and in much the same way as it is done elsewhere in

27 The ILC is presently completing an important set of draft articles on the "Protection of the Environment in relation to Armed Conflicts". See, previously, UNEP (2009). 
international law, the Pact does provide in generalised terms in draft Article 20 that "[T] he special situation and needs of developing countries, particularly the least developed and those most environmentally vulnerable, shall be given special attention". It also reiterates verbatim the Paris Climate Agreement's qualification that parties have common but differentiated responsibilities determined by their respective capabilities in the light of different national circumstances (article 2.2). This language was specific to the politics of the climate change regime and arguably a broader commitment to solidarity still exists within IEL, as evidenced by the extant principle 7 of the Rio Declaration. ${ }^{28}$ A more ambitious commitment that pursues global equity between states and peoples would have been a positive development, which we believe could encourage more deliberate and effective involvement of the Global South in global environmental governance.

While there is no compliance mechanism to oversee the observance, protection and implementation of the substantive and procedural environmental human rights of the Pact, draft article 21 does provide for a general "compliance mechanism to facilitate implementation of, and to promote compliance with, the provisions" of the Pact. It is foreseen by the Pact itself that this mechanism will consist of a committee of independent experts, and very much like the Aarhus Compliance Mechanism, it will focus on facilitation in a "transparent, non-adversarial and non-punitive manner" (draft article 21). While the jury is still out on whether such a soft non-punitive, consultative strategy is to be preferred in global environmental governance as opposed to a more punitive command-and-control system, the provision of a compliance mechanism is commendable and should go some way towards promoting observance of the Pact's provisions. We also find it surprising that the drafters of the Pact did not think it appropriate or necessary to provide the foundations here for the establishment of a global environmental court that has jurisdiction over global environmental disputes, the creation of which could aid the peaceful settlement of global environmental disputes under the auspices of the rule of law (Rest 1998; but see Hey 2000). We would suggest that the inclusion of such a judicial structure should at least be considered by states.

\section{Conclusion}

The Global Pact presents an important opportunity that could offer a radically different alternative for a globally binding instrument aimed at overcoming many of the failures of IEL, while also confronting some of the Anthropocene's socio-ecological challenges. But disappointingly, and apart from some exceptions, the Pact brings little new to the table. A plain reading of the Pact in its present iteration suggests that it often regurgitates many, though not all, generally accepted principles of IEL and that it is mostly devoid of an ecocentric ethic of socio-ecological care. As it stands, the Pact is neither nearly as radical as it could have been, nor as it should be, if it is to act as an ethically based higher-order

\footnotetext{
28 "States shall co-operate in a spirit of global partnership to conserve, protect and restore the health and integrity of the Earth's ecosystem. In view of the different contributions to global environmental degradation, States have common but differentiated responsibilities. The developed countries acknowledge the responsibility that they bear in the international pursuit of sustainable development in view of the pressures their societies place on the global environment and of the technologies and financial resources they command".
} 
normative instrument that binds states to clear obligations that could address the socioecological crisis of the Anthropocene.

In the light of its ambition, and subject to the evaluative criteria just outlined, we are therefore deeply unsure that the Global Pact in its present draft form adds significantly to the legal panoply of environmental norms, hard or soft. Other commentators, such as Biniaz, have come to a similar conclusion: "[T]here is a legitimate question whether... [the Pact] would add value or might, in fact, end up simply creating legal confusion and negatively affecting existing legal regimes" (Biniaz 2017: 11). While it has some diplomatic and symbolic aspirations and relevance-often around the resigned view that any document is better than none-in its present form it does not constitute a firm foundation for inaugurating or embedding the type of paradigm-shifting global juridical regime that we critically need in the Anthropocene. Unless considerably revised and strengthened, it will at best be a broadly supported but weak agreement, and at worst will remain a stillborn initiative to be shelved alongside the numerous other failures of the legal fraternity in their efforts to address the mounting socio-ecological crisis we find ourselves in. Or is the opposite true? Would it be worse that an inadequate document is entrenched, failing to reflect the necessary Lex Anthropocenae?

The Global Pact will undergo significant changes during the future negotiation process that might, or might not, lead to its eventual adoption. States therefore still have an opportunity to revise its content so that it more fully and forcefully provides for radical measures aimed at protecting Earth system integrity. It is our hope that it will be drastically revised, because in its present form, even if it were to be adopted by states as a binding document, there are genuine reasons to be concerned as to its normative effect.

These can be broadly grouped into three summary critiques. First, it does not provide a complete and normatively rich codification of current IEL. As noted above, there are principles which are absent, and for those that are included, they often fail to reflect fully present normative understandings. We believe a partial codification might be argued to be no codification at all. Second, the Pact fails to raise normative ambition to include new provisions. There are several innovative provisions that could have been included, such as: specifically replacing the anthropocentric orientation of the Pact's provisions with an ecocentric one; embedding a far more deliberate Earth system approach in all of the provisions of the Pact; supplementing the decades-old principles of IEL with principles such as in dubio pro natura, Earth system integrity and intra-generational and intra-species justice and equity; introducing binding obligations for non-state actors (particularly transnational corporations) that harm people and the environment; providing for the rights of nature; and introducing the concept of planetary boundaries as a minimum threshold or standard that IEL must strive to achieve and maintain. Though outside the Pact presently, these principles are not as radical as they appear at first glance; many have already been broadly endorsed by the IUCN World Commission on Environmental Law in its 2016 World Declaration on the Environmental Rule of Law (IUCN 2016).

And third, the provisions on monitoring, implementation, compliance and dispute settlement seem particularly weak. Combined with almost no understanding as to how this Pact, as a treaty of general application, will coexist alongside other MEAs and rules of customary IEL, there must be genuine questions not only as to what the Pact is for (an objective assessment), but also how (and whether) States might use the Pact to their own advantage (a subjective assessment). As a means of regulating and promoting positive behaviour both of themselves and others, the Pact is largely silent.

In the Introduction, we also raised a further concern: the possibility that the Pact creates a false sense of security - that it would be retrogressive to entrench an inadequate 
document which fails to reflect the imperative of new law, which we term Lex Anthropocenae. It is to that we turn, briefly, in conclusion. Koskenniemi has noted that "[I]nternational law does not contain a ready-made blueprint for a better world that could only be 'applied' so as to bring about peace and justice. Instead it contains arguments and positions..." (Koskenniemi 2012: 59). We recognise the textual limitations of a Pact; that words alone cannot change behaviour. But we believe better words can prompt better behaviour. Scientific reality and ethical reality are increasingly coalescing around the viewpoint that the present, traditional, state-bound law is insufficient. We do not as yet have an answer-there is no "ready-made blueprint"- but we would argue that the Pact could have an enormously important role to play in addressing the lacunae in the current normative system, to push for a more ambitious normative framework, and as a means to address systemic challenges and increase the normative power of ecological norms. We call this law the Lex Anthropocenae. It is in evolution, it exists within those "arguments and positions". Others might not share the same values and will dispute the necessity of such fundamental change. That is part of the discourse. We are increasingly of the view, however, that a "lex anthropocenae would provide a freedom for imagining both the process and purpose of reform beyond that which our present normative restrictions ordinarily permit" (French forthcoming). In reviewing the draft Pact, states will undoubtedly be aware of the reality that intergovernmental negotiations usually water down the starting document rather than increasing its normative strength, or viscosity. We fear the opportunity for radical inclusion may have already been lost. But there is another reality, that of ecological justice, which cannot be "applied" from without but must be argued over and won from within if documents such as the Pact are to begin addressing the perilous state of the Earth.

Funding Funding was provided by H2020 Marie Skłodowska-Curie Actions (751782).

Open Access This article is distributed under the terms of the Creative Commons Attribution 4.0 International License (http://creativecommons.org/licenses/by/4.0/), which permits unrestricted use, distribution, and reproduction in any medium, provided you give appropriate credit to the original author(s) and the source, provide a link to the Creative Commons license, and indicate if changes were made.

\section{References}

Baskin, J. (2015). Paradigm dressed as epoch: The ideology of the Anthropocene. Environmental Values, 24(1), 9-29.

Beyerlin, U. (2007). Different types of norms in international environmental law: Policies, principles, and rules. In D. Bodansky, J. Brunnée, \& E. Hey (Eds.), Oxford handbook of international environmental law (p. 425). Oxford: Oxford University Press.

Biermann, F. (2014). Earth system governance: World politics in the Anthropocene. Cambridge: MIT Press.

Biniaz, S. (2017). 10 questions to ask about the proposed "Global Pact for the Environment". Sabin Centre for Climate Change Law. Accessed July 31, 2018, from http://columbiaclimatelaw.com/files/2017/08/ Biniaz-2017-08-Global-Pact-for-the-Environment.pdf.

Bosselmann, K. (2016). Shifting the legal paradigm: Earth-centred law and governance. In P. Magalhães, et al. (Eds.), The safe operating space treaty: A new approach to managing our use of the earth system (pp. 64-82). Newcastle upon Tyne: Cambridge Scholars Publishing.

Bosselmann, K., \& Engel, R. (Eds.). (2010). The earth charter: A framework for global governance. Amsterdam: KIT Publishers.

Boyd, D. (2011). The environmental rights revolution: A global study of constitutions, human rights and the environment. Vancouver: UBC Press.

Burger, M., et al. (2018), Global perspectives on a Global Pact for the environment (Sabin Center for Climate Change Law, Columbia University New York), blogpost September 20, 2018. 
Caldwell, L., \& Weiland, P. (1996). International environmental policy: From the twentieth to the twentyfirst century (3rd ed.). Durham: Duke University Press.

Calzadilla, P. V., \& Kotzé, L. (2018). Living in harmony with nature?. A critical appraisal of the rights of Mother Earth in Bolivia: Transnational Environmental Law. https://doi.org/10.1017/S204710251 8000201 .

Carnwath, J. (2018). Climate justice and the Global Pact. https://www.supremecourt.uk/docs/speech-18022 6.pdf. Accessed September 25, 2018.

Chapron, G., Epstein, Y., Trouwborst, A., \& López-Bao, J. (2017). Bolster legal boundaries to stay within planetary boundaries. Nature Ecology and Evolution, 1, 1-5.

Chimni, B. S. (2006). Third world approaches to international law: a manifesto. International Community Law Review, 8, 3-27.

Cosens, B. A. (2013). Legitimacy, adaptation, and resilience in ecosystem management. Ecology and Society. https://doi.org/10.5751/ES-05093-180103.

Dalby, S. (2016). Framing the Anthropocene: The good, the bad and the ugly. The Anthropocene Review, $3(1), 33-51$.

Ebbesson, J., Gaugitsch, H., Jendroska, J., Marshall, F., \& Stec, S. (Eds.). (2014). The Aarhus convention: An implementation guide (2nd ed.). Geneva: UN Economic Commission for Europe.

Engel, R. (2004). A covenant model for global ethics. Worldviews, 8(1), 29-46.

European Parliament. (2018). Resolution of 16 January 2018 on international ocean governance: An agenda for the future of our oceans in the context of the 2030 SDGs (P8_TA-PROV(2018)0004). Accessed July 31, 2018, from http://www.europarl.europa.eu/sides/getDoc.do?pubRef=-//EP// TEXT+TA+P8-TA-2018-0004+0+DOC+XML+V0//EN\&language $=$ EN.

Fernández, E. F., \& Malwé, C. (2018). The emergence of the 'planetary boundaries' concept in international environmental law: A proposal for a framework convention. Review of European, Comparative and International Environmental Law, 1-9.

French, D. (forthcoming). Inter-state adjudication in the transition to the Anthropocene: Compulsion or diversity? In U. Khaliq \& J. Hartmann (Eds.), The achievements of international law: Essays in honour of Robin Churchill. Oxford: Hart.

French, D., \& Kotzé, L. (Eds.). (2018). Sustainable development goals: Law, theory and implementation. Cheltenham: Edward Elgar.

French, D., \& Scott, K. N. (2018). International environmental law. In M. Bowman \& D. Kritsiotis (Eds.), Conceptual and contextual perspectives on the modern law of treaties (pp. 677-709). Cambridge: Cambridge University Press.

Gonzales, C. (2017). Global justice in the Anthropocene. In L. Kotzé (Ed.), Environmental law and governance for the Anthropocene (pp. 219-240). Oxford: Hart.

Grove, K., \& Chandler, D. (2017). Introduction: Resilience and the Anthropocene: The stakes of 'renaturalising' politics. Resilience, 5(2), 79-91.

Gupta, J., \& Sanchez, N. (2012). Global green governance: Embedding the green economy in a global green and equitable rule of law polity. Review of European Community and International Environmental Law, 21(1), 12-22.

Haff, P. (2014). Humans and technology in the Anthropocene: Six rules. The Anthropocene Review, 1(2), $126-136$.

Haus der Kulturen der Welt. (2013). The Anthropocene project. Accessed July 31, 2018, from https:// www.hkw.de/media/en/texte/pdf/2013_2/programm_6/anthropozaen/booklet_anthropozaen_eine_ eroeffnung.pdf.

Hey, E. (2000). Reflections on an international environmental court. Leiden: Brill.

Hey, E. (2015). The interaction between human rights and the environment in the European "Aarhus space”. In A. Grear \& L. Kotzé (Eds.), Research handbook on human rights and the environment (pp. 353-376). Cheltenham: Edward Elgar.

International Law Association. (2012). Sofia guiding statements on the judicial elaboration of the 2002 New Delhi declaration of principles of international law relating to sustainable development. Copy on file with authors and available on request.

International Law Association. (2014). Study group on due diligence in international law first report. Accessed July 31, 2018, from https://olympereseauinternational.files.wordpress.com/2015/07/due_ diligence_-_first_report_2014.pdf.

International Law Association. (2016). Study group on due diligence in international law second report. Copy on file with authors and available on request.

IUCN. (1994 (5th edn. 2015)). Draft international covenant on environment and development: Implementing sustainability. Accessed July 31, 2018, from https://portals.iucn.org/library/node/46647. 
IUCN. (2016). IUCN world declaration on the environmental rule of law. https://www.iucn.org/sites/ dev/files/content/documents/english_world_declaration_on_the_environmental_rule_of_law_final .pdf. Accessed 14 Oct 2018.

Kim, R., \& Bosselmann, K. (2013). International environmental law in the Anthropocene: Towards a purposive system of multilateral environmental agreements. Transnational Environmental Law, 2(2), 285-309.

Klare, M. T. (2002). Resource wars: The new landscape of global conflict. New York: Henry Holt and Company.

Knox, J. (2018). Newsletter 30 July 2018. http://srenvironment.org/wp-content/uploads/2018/07/news1 etter-28-July-2018.pdf.

Koskenniemi, M. (2012). International law in the world of ideas. In J. Crawford \& M. Koskenniemi (Eds.), The Cambridge companion to international law (pp. 47-63). Cambridge: Cambridge University Press.

Kotzé, L. (2014). Fragmentation revisited in the context of global environmental law and governance. South African Law Journal, 131(3), 548-583.

Kotzé, L. (2016). Global environmental constitutionalism in the Anthropocene. Oxford: Hart.

Kotzé, L. (Ed.). (2017). Environmental law and governance for the Anthropocene. Oxford: Hart.

Kotzé, L. (2018). The sustainable development goals: An existential critique alongside three new-millennial analytical paradigms. In D. French \& L. Kotzé (Eds.), Sustainable development goals: Law, theory and implementation (pp. 41-65). Cheltenham: Edward Elgar.

Kotzé, L., \& Calzadilla, P. V. (2017). Somewhere between rhetoric and reality: Environmental constitutionalism and the rights of nature in Ecuador. Transnational Environmental Law, 6(3), 401-433.

Kovar, J. (1993). A short guide to the Rio declaration. Colorado Journal of International Environmental Law and Policy, 4(1), 119-140.

Le Club de Juristes. (2017). White paper: Toward a Global Pact for the environment. Paris: Le Club de Juristes.

Le Club de Juristes. (2017b). Global Pact for the environment. Accessed September 24, 2018, from https ://www.iucn.org/sites/dev/files/content/documents/draft-project-of-the-global-pact-for-the-environmen t.pdf.

Lebada, A. M. (2018). Delegates set agenda for first session on Global Pact for environment. Accessed September 24, 2018, from http://sdg.iisd.org/news/delegates-set-agenda-for-first-session-on-global-pactfor-environment/.

Lewis, S., \& Maslin, M. (2015). Defining the Anthropocene. Nature, 519(7542), 171-180.

Mackey, B. (2004). The earth charter and ecological integrity: Some policy implications. World Views, 8(1), 76-92.

Magalhães, P., et al. (Eds.). (2016). The safe operating space treaty: A new approach to managing our use of the earth system. Newcastle upon Tyne: Cambridge Scholars Publishing.

Moltmann, J. (1991). Reconciliation with nature. Word and World, 11(2), 117-123.

Nicholls, S. (2010). The global covenant: The earth charter and the concept of covenants in international law and environmental governance. New Zealand Journal of Environmental Law, 14, 103-133.

O'Gorman, R. (2017). Environmental constitutionalism: A comparative study. Transnational Environmental Law, 6(3), 435-462.

Payne, C. (2018). A Global Pact for the environment. ASIL Insights, 22(12). https://www.asil.org/insights/ volume/22/issue/12/global-pact-environment\#_edn4. Accessed 14 Oct 2018.

Raith, J. (2018). The 'Global Pact for the environment': A new instrument to protect the planet? Journal for European Environmental and Planning Law, 15(1), 3-23.

Redclift, M. (2005). Sustainable development (1987-2005): An oxymoron comes of age. Sustainable Development, 13(4), 212-227.

Rest, A. (1998). The indispensability of an international environmental court. Review of European, Comparative and International Environmental Law, 7(1), 63-67.

Richardson, B. J. (2011). A damp squib: Environmental law from a human evolutionary perspective. Comparative research in law and political economy, research paper no. 8/2011. http://dx.doi.org/10.2139/ ssrn. 1760043.

Rockström, J., et al. (2009). Planetary boundaries: Exploring the safe operating space for humanity. Ecology and Society, 14(2), 1-33.

Ruggie, J. (2008). Protect, respect and remedy: A framework for business and human rights of 2008. https ://www.business-humanrights.org/sites/default/files/reports-and-materials/Ruggie-report-7-Apr-2008. pdf. Accessed 14 Oct 2018.

UN. (2007). Yearbook of the International Law Commission 2001 vol II part 2: Report of the commission to the general assembly on the work of its fifty-third session. New York: UN. 
UN Economic and Social Council. (2003). Norms on the responsibilities of transnational corporations and other business enterprises with regard to human rights (26 August 2003) (E/CN.4/Sub.2/2003/12/ Rev.2). Accessed July 31, 2018, from, https://documents-dds-ny.un.org/doc/UNDOC/GEN/ G03/160/08/PDF/G0316008.pdf?OpenElement.

UN Human Rights Council. (2011). Guiding principles on business and human rights: Implementing the United Nations "protect, respect and remedy" framework annexed to report of the special representative of the secretary-general on the issue of human rights and transnational corporations and other business enterprises (21 March 2011) (A/HRC/17/31). Accessed July 31, 2018, from https://www. ohchr.org/Documents/Issues/Business/A-HRC-17-31_AEV.pdf.

UN Human Rights Council. (2018). Report of the Special Rapporteur on the issue of human rights obligations relating to the enjoyment of a safe, clean, healthy and sustainable environment (24 January 2018) (A/HRC/37/59). Accessed July 31, 2018, from https://documents-dds-ny.un.org/doc/UNDOC/GEN/ G18/017/42/PDF/G1801742.pdf?OpenElement.

UNEP. (2009). Protecting the environment during armed conflict: An inventory and analysis of international law. Nairobi: UNEP.

UNGA. (2009). Harmony with nature. Resolution adopted by the general assembly on 21 December 2009 (A/RES/64/196). Accessed July 31, 2018, from http://www.un.org/en/ga/search/view_doc.asp?symbo l=A/RES/64/196.

UNGA. (2014). Harmony with nature. Report of the secretary-general of 18 August 2014 (A/69/322). Accessed July 31, 2018, from https://azdoc.site/322-harmony-with-nature-report-of-the-secretarygeneral-summ.html.

UNGA. (2017). Permanent sovereignty of the Palestinian people in the occupied Palestinian territory, including East Jerusalem, and of the Arab Population in the occupied Syrian Golan over their natural resources. Resolution adopted by the general assembly on 20 December 2017 (A/RES/72/240). Accessed July 31, 2018, from https://digitallibrary.un.org/record/1479663/files/A_RES_72_240-EN. pdf.

UNGA. (2018). Towards a Global Pact for the environment. Resolution adopted by the general assembly on 10 May 2018 (A/RES/72/277). Accessed July 31, 2018, from http://www.un.org/en/ga/search/view_ doc.asp?symbol=A/RES/72/277.

World Commission on Environmental Law. (2017). Global Pact for the environment introduced to the world. Accessed July 31, 2018, from https://www.iucn.org/commissions/world-commission-environmentallaw/events-wcel/past-events-wcel/global-pact-environment-introduced-world.

Young, M. (2018). Global Pact for the environment: defragging international law? Accessed September 24, 2018, from https://www.ejiltalk.org/global-pact-for-the-environment-defragging-international-law/.

Zalasiewicz, J., et al. (2017). The working group on the Anthropocene: Summary of evidence and interim recommendations. Anthropocene, 19, 55-60. 